\title{
Modelo extractivo en Argentina (1990-2016): ¿del extractivismo clásico neoliberal al neoextractivismo progresista? Tres estudios de caso ${ }^{1}$
}

\section{Extractivist Model in Argentina (1990-2016): From Classic Neoliberal Extractivism to Progressive Neo- Extractivism? Three Case Studies}

Sebastián Gómez-Lende ${ }^{2}$

Investigador Adjunto de Conicet, IGEHCS

Conicet/UNCPBA, Tandil, Argentina

gomezlen@fch.unicen.edu.ar

http://orcid.org/0000-0002-3510-9650

Recibido: 06-10-2017

Aprobado: $26-10-2018$

1 Este artículo se enmarca en el proyecto “Orden global y acumulación por desposesión: implicancias sociales, económicas, políticas, ambientales y sanitarias de los usos extractivos del territorio en la Argentina (1990-2018)". Consejo Nacional de Investigaciones Científicas y Técnicas. 
Modelo extractivo en Argentina (1990-2016):

¿del extractivismo clásico neoliberal al neoextractivismo progresista? Tres estudios de caso

\section{Resumen}

Conforme a la literatura, el actual paradigma neoextractivista latinoamericano diferiría del modelo extractivo "clásico" neoliberal debido al menor peso relativo del capital privado extranjero y la captación por parte del Estado de gran parte del excedente generado a través de distintos mecanismos (reformas normativo-institucionales, aumento de tributos, creación de empresas públicas, imposición de derechos de exportación, etc.). Este artículo examina críticamente esas tesis y las contrasta empíricamente para la Argentina analizando los casos del agronegocio, la pesca marítima y la minería metalífera. Contrariamente a lo establecido por la literatura, los resultados muestran que el modelo extractivo argentino no representa un "progresismo neodesarrollista" puro, sino más bien un patrón de acumulación extremadamente contradictorio, donde la mayor intervención estatal coexiste con la mayor presencia del capital privado extranjero y donde el predominio de los atributos clásicos neoliberales o de los modernos rasgos neoextractivistas varía según las actividades económicas involucradas.

Palabras clave: extractivismo; neoliberalismo; progresismo; Argentina.

\section{Abstract}

According to the literature, the current Latin American neo-extractivist paradigm would differ from the neoliberal, "classic" extractive pattern due to the lower relative weight of foreign private capital and, consequently, the appropriation by the State of a substantial piece of the surplus through several mechanisms (e.g. normative and institutional reforms, increase of pre-existent taxes, creation of public enterprises, imposing export taxes, etc.). This paper critically examines such claims and empirically contrasts them for the Argentinean case by analyzing three sectors: agribusiness, sea fishing, and metal mining. Opposite to the literature's statements, the article's findings show that the Argentinean extractive pattern does not represent a model of pure neo-developmentalist progressivism but an extremely paradoxical accumulation regime where the larger State intervention coexists with the growing presence of foreign private capital and where the dominance of the classic, neoliberal attributes and the modern neo-extractivist features strongly depends on the economic activities considered.

Keywords: extractive industries; neoliberalism; progressivism; Argentina.

¿Cómo citar este artículo? / How to quote this article?

Gómez-Lende, S. Modelo extractivo en Argentina (1990-2016): ¿del extractivismo clásico neoliberal al neoextractivismo progresista? Tres estudios de caso. Sociedad y Economía, (36), 82-105. https://doi.org/10.25100/sye.voi36.7458 


\section{Introducción}

En el período histórico contemporáneo, una nueva oleada de usos extractivos del territorio reproduce y consolida el rol geopolítico tradicionalmente asignado a América Latina dentro de la división internacional del trabajo. Conforme a los aportes del académico uruguayo Eduardo Gudynas (2009; 2012; 2015), el actual paradigma neoextractivista latinoamericano diferiría del modelo extractivo "clásico" neoliberal debido al menor peso relativo del capital privado extranjero y al papel más activo del Estado, que habría abandonado su papel garantista de antaño para convertirse en interventor, regulador, actor directo y legitimador de dicho patrón de acumulación. Esta situación habría permitido al Estado captar gran parte del excedente a través de reformas normativo-institucionales, aumento de tributos, creación de empresas públicas e imposición de derechos de exportación para posteriormente canalizarlo hacia el financiamiento de programas asistencialistas de reducción de la pobreza. Así, el neoextractivismo sería, por definición, progresista, neodesarrollista o, al menos, posneoliberal.

Sometiendo estas tesis a un riguroso examen crítico, este artículo las contrasta empíricamente con el caso argentino durante el período 19902015, abarcando las fases neoliberal (1990-2001) y neodesarrollista (2002-2015) del modelo, recurriendo para ello al análisis exhaustivo de tres actividades extractivas concretas: el agronegocio en general (con énfasis en la soja), la pesca marítima y la minería metalífera. La elección de dichos sectores obedeció al hecho de que éstos forman parte del núcleo duro de la matriz primario-extractiva exportadora argentina, que explica casi el $60 \%$ de la inserción del país en el mercado mundial.

Contrariamente a la literatura académica de referencia, el trabajo sostiene las siguientes hipótesis: a) respecto del modelo extractivo, la pretendida antinomia entre neoliberalismo y neodesarrollismo es falsa, debido a que en Argentina las reformas instauradas por el primero sentaron las bases estructurales para el ulterior desarrollo del segundo, el cual a su vez preservó y agudizó los rasgos legados por el anterior; b) el modelo argentino no es netamente "neoextractivista neodesarrollista progresista", sino que se caracteriza por la coexistencia de actividades económicas cuyo desempeño se ajusta en parte a esa dinámica y sectores donde el rol subsidiario del Estado sugiere la continuidad aggiornada del extractivismo clásico neoliberal del pasado; y c) el patrón de acumulación resultante es extremadamente contradictorio, pues el Estado no siempre participa a gran escala en la apropiación de la renta extractiva de los distintos sectores (y cuando lo hace, resigna parte de esos ingresos en manos del capital), en tanto que la mayor intervención estatal se encamina más a fomentar la extranjerización de la matriz extractiva y servir a "amigos" del poder político que a "derramar" riqueza hacia las capas sociales más postergadas.

El artículo comienza desarrollando un abordaje teórico-conceptual que discute los conceptos de extractivismo y usos del territorio, y debate críticamente aspectos políticos de algunas tesis de Gudynas. Seguidamente, se presenta una apretada síntesis de las fases neoliberal y neodesarrollista del modelo extractivo argentino y se describe la creciente reprimarización de la matriz exportadora doméstica. Núcleo del artículo, el tercer apartado analiza el papel del Estado y las políticas públicas en el agronegocio, la pesca marítima y la minería metalífera, procurando distinguir si estos sectores operan conforme a los parámetros del "neoextractivismo progresista" o bien continúan funcionando de acuerdo con los criterios heredados del "extractivismo clásico neoliberal". Finalmente, se presentan las conclusiones del trabajo.

\section{Usos extractivos del territorio en América Latina. ¿Extractivismo clásico o neoextractivismo? Tesis y debates}

Siguiendo a Santos y Silveira (2001), el objeto de interés de la geografía no es el territorio en sí mismo, sino el territorio usado. Síntesis de la configuración material y la dinámica social, en cada período histórico los usos del territorio revelan las formas, acciones, normas, agentes, funciones, estructuras y procesos (Santos, 1996; Silveira, 1999) 
emergentes de un modelo de acumulación dado. Actualmente, en los países periféricos gran parte de los usos hegemónicos del territorio integra la matriz del denominado modelo extractivista.

Si bien la vasta difusión del término en la literatura latinoamericana no siempre ha sido acompañada por niveles similares de precisión conceptual (Portillo, 2014), el extractivismo puede definirse como un modelo de acumulación basado en: a) la conversión de bienes comunes en mercancías; b) la explotación intensiva de grandes volúmenes de recursos naturales a un ritmo acelerado incompatible con los tiempos de reposición de la naturaleza; c) el escaso o nulo grado de procesamiento local, regional y/o nacional de dichos bienes; y d) la exportación de materias primas para abastecer la industria y/o el consumo de los países centrales, generando en el proceso rentas extraordinarias mayoritariamente captadas por agentes externos (Seoane, 2013; Gudynas, 2015; Acosta, 2016).

Este modelo de acumulación implica vastas escalas de producción, uso intensivo de tecnología de punta y desmesurado consumo de recursos no reproducibles (agua, suelo fértil, biodiversidad, etc.), se orienta casi exclusivamente al mercado mundial, genera grandes flujos de valor de cambio condensados en rentas diferenciales a escala mundial que reportan ganancias siderales al capital concentrado, no resuelve necesidades internas, $y$ es extremadamente conflictivo debido a sus enormes deseconomías externas (impactos ambientales, desplazamiento masivo de actividades preexistentes, campesinos, aborígenes, trabajadores rurales y población, etc.) (Giarracca y Teubal, 2013). Su patrón de organización espacial estructura y reproduce una matriz socio-productiva excesivamente especializada, donde el territorio pasa a ser usado exclusivamente como si de un mero recurso se tratara y la economía de enclave se convierte en la forma arquetípica hegemónica de articulación local con el mercado mundial. Como resultado, las regiones implicadas pasan a operar como colonias-commodities (Machado, 2013) donde coexisten la concentración y extranjerización de los recursos y la riqueza, el acelerado crecimiento exportador, la subordinación, dependencia y vulnerabilidad político-económica y los graves impactos socio-ambientales del modelo.

En el campo de las ciencias sociales, la problemática del extractivismo ha cobrado relevancia gracias a los esfuerzos de la ecología política. Sin perjuicio de lo anterior, debe destacarse que a comienzos del siglo XXI las geografías alemana y francesa consideraron las formas extractivas de acumulación como objeto de preocupación y categoría de análisis, definiéndolas como 'economías de rapiña tropicales' o 'hechos de ocupación destructiva' (Brunhes, 1942; Ruiz, 2014). En la actualidad, a la definición tradicional del concepto se han incorporado nuevos recursos y ramas económicas (monocultivos de exportación, biocombustibles, foresto-industria, pesca) que explotan una biomasa teóricamente renovable dentro de ciertos límites pero cuya lógica productivista actual rebasa los umbrales naturales de reproducción del recurso. A esto deben añadirse el turismo internacional de lujo, las actividades que operan como input y condición sine qua non para el acceso del capital a ciertas fuentes de materias primas (megarrepresas hidroeléctricas, faraónicos proyectos de infraestructura de transporte y comunicación) (Svampa, 2011; Seoane, 2013), y los extractivismos de nueva generación (Gudynas, 2015), formas modernas de actividades extractivas antiguas (minería metalífera a cielo abierto, extracción hidrocarburífera por fractura hidráulica, etc.).

Sin duda alguna, el período histórico contemporáneo es escenario del despliegue de una nueva avanzada u oleada de usos extractivos del territorio que se cierne sobre América Latina. En esta suerte de relanzamiento ampliado del rol geopolítico clásico asignado a la región dentro de la división internacional del trabajo, sus territorios y bienes naturales adquieren renovado protagonismo al ser concebidos por el capital como una fuente privilegiada de biodiversidad, tierra, agua, alimentos, hidrocarburos y minerales que aseguraría la reproducción a bajo costo y el consumo sostenido de las economías centrales (Composto, 2012). En virtud de esta realidad empírica, Gudynas (2009) afirma que a comienzos del siglo XXI surgió un modelo neoextractivista 
latinoamericano caracterizado por: a) la persistente importancia de los sectores primario-extractivos, pese a la crisis neoliberal y el viraje ideológico continental hacia el progresismo; b) el papel más activo del Estado, que interviene fijando andamiajes regulatorios más claros (renegociación de contratos, elevación de regalías y tributos, creación y/o expansión de empresas estatales) no necesariamente orientados a servir a "amigos" del poder político; y c) la captación por parte del Estado de una porción sustancial del excedente así generado para financiar programas asistencialistas y legitimar socio-políticamente el modelo. Si bien el planteo resultó convincente a la luz del ciclo de alza de los precios internacionales de commodities, la realidad empírica latinoamericana muestra la necesidad de analizar más profundamente los aspectos políticos de esos presupuestos teóricos.

Según Gudynas (2009), las tesis sucintamente enumeradas más arriba configurarían un patrón de acumulación presumiblemente diferente del extractivismo "clásico", al cual define como un modelo caracterizado por delegar totalmente en el capital privado extranjero la responsabilidad por el proceso extractivo. Aquí el papel del Estado se limitaría al rol de mero garante, fijando controles acotados y normas orientadas a minimizar, negar y/o reprimir las protestas ciudadanas ante los impactos del modelo, sin jamás intervenir directamente en la captación y redistribución del excedente (Gudynas, 2012). Sin embargo, Lander (2014) objeta que no existirían diferencias sustantivas entre extractivismo clásico y neoextractivismo; de hecho, ambos se basan en un mismo modelo de desarrollo sustentado en la continuidad y expansión del patrón productivo primario exportador, independientemente del mayor control estatal, la nacionalización parcial de beneficios y su reinversión en políticas públicas de reducción de pobreza y mitigación de desigualdades sociales. Así pues, el neoextractivismo no sería más que un extractivismo posneoliberal donde el Estado regula la apropiación de recursos y rentas y explota directamente la naturaleza so pretexto de favorecer el interés nacional, asegurar la soberanía y la estabilidad política y reducir la pobreza.
De acuerdo con Gudynas, el neoextractivismo sería progresista, neodesarrollista o, al menos, posneoliberal. De hecho, es importante señalar que en algunos países de América Latina el neoextractivismo es a menudo presentado como una alternativa al neoliberalismo. Sin embargo, lo cierto es que este último fue quien sentó las bases de sustentación del modelo actual en toda la región. Independientemente de la comprensible e indudable influencia de las racionalidades extractivas pretéritas heredadas, las reformas neoliberales de fines del siglo $\mathrm{XX}$ acicatearon el productivismo y condujeron a la reprimarización económica y la privatización, desregulación y extranjerización a gran escala de recursos naturales. La oposición entre neoliberalismo y neoextractivismo es, pues, una falsa antinomia: el nacimiento y la expansión del segundo han dependido indudablemente de la capitalización y agudización de las metamorfosis sociales, políticas, económicas y territoriales impuestas por el primero, rejuvenecidas por la utilización lábil y oportunista de ciertas categorías políticamente correctas (desarrollo sustentable, responsabilidad social empresarial, gobernanza) (Svampa, 2011).

Si a su vez se retrocede en la línea del tiempo, se observan en varios países latinoamericanos experiencias que, medio siglo antes de que se acuñara el concepto, merecerían el rótulo de neoextractivistas. La estatización del estaño boliviano en 1952 y la nacionalización del cobre chileno en 1971 (donde previamente a esta política el Estado ya captaba $60 \%$ de la renta de este mineral) son buenos ejemplos, al igual que el caso de la petrolera estatal argentina YPF, que detentó el monopolio jurídico sobre la extracción hidrocarburífera durante setenta años (1922-1992). Como resultado, y contrariamente a lo que plantea Gudynas (2012), el supuesto rol subordinado que asumiría el empresariado transnacional en el modelo extractivo latinoamericano no es un atributo singular o específico de la fase actual.

Otro punto débil de la propuesta de Gudynas es que sus tesis se basan en el supuesto viraje ideológico continental hacia el progresismo. Sin 
Modelo extractivo en Argentina (1990-2016):

¿del extractivismo clásico neoliberal al neoextractivismo progresista? Tres estudios de caso

embargo, la complejidad de la realidad política latinoamericana excede tal aseveración. Existen países donde se desarrolla una suerte de 'socialismo comunitario' basado en la nacionalización de sectores económicos estratégicos y la socialización de la riqueza. Otros son escenario del neoliberalismo de guerra, donde la continuidad exacerbada del auge neoliberal del pasado implica una recolonización político-económica-territorial descarnada (tratados de libre comercio con Estados Unidos, estrategias de contrainsurgencia, aceptación genuflexa de disposiciones de la OMC, el Banco Mundial y el FMI). Y otros apuntan al neodesarrollismo, recuperando la retórica nacional-popular de los años de 1950 a través del desmantelamiento (parcial y no estructural) de ciertos instrumentos y políticas neoliberales (Composto, 2012). Lo que cierto es que, pese a sus diferencias, los tres proyectos se basan en la explotación y exportación de bienes naturales, independientemente de si esto favorece el supuesto bienestar de las masas populares, el beneficio exclusivo del capital transnacional o una hibridación de ambas tendencias.

$\mathrm{Al}$ respecto, Gudynas postula la preeminencia en Perú y Colombia del extractivismo convencional -es decir, liberal o conservador, ligado a empresas transnacionales y el rol subsidiario del Estado- y considera como neoextractivistas naciones como Venezuela, Ecuador, Bolivia, Argentina y Brasil, donde el Estado sería mucho más activo captando renta y ejerciendo la propiedad/gestión de los recursos naturales a través de la renegociación de contratos, la elevación de tributos y regalías, la expropiación de firmas privadas, la reestatización de empresas privatizadas y la creación de nuevas compañías públicas (Gudynas, 2015). Este axioma podría ser válido siempre y cuando el análisis se desarrollara en un contexto de agregación económica y territorial; el problema con esta tesis es que considera los distintos países como bloques homogéneos, sin reparar en sus diferencias internas regionales y sectoriales. No obstante, y como se verá a lo largo de este trabajo para el caso argentino (un país neoextractivista progresista, según Gudynas), en un mismo territorio pueden coexistir actividades donde el papel del Estado podría ser juzgado como progresista y sectores donde lo que predomina es la continuidad aggiornada del extractivismo clásico neoliberal.

\section{Fases del modelo extractivo contemporáneo en Argentina: del neoliberalismo (1990-2001) al neodesarrollismo (2002-2016)}

Organizado en función del Consenso de Washington y los intereses del capitalismo estadounidense, el modelo neoliberal implementado durante la década de 1990 impuso un conjunto de reformas estructurales que refuncionalizaron drásticamente la economía nacional y redefinieron profundamente el rol del Estado. Sobresalen, entre otras, la liberalización comercial y financiera, la privatización masiva de empresas públicas, el meteórico endeudamiento externo, la apertura importadora, la desregulación de la economía, la apertura indiscriminada al capital extranjero, la implementación de una política monetarista de paridad nominal entre el peso argentino y el dólar estadounidense (el plan de convertibilidad), la flexibilización laboral y la desindustrialización, tercerización y reprimarización de la matriz económica. Los ejes de acumulación privilegiados por esta nueva lógica fueron el comercio internacional, la lógica financiera especulativa, las extraordinarias rentas asociadas a las privatizaciones y la explotación extranjerizada de recursos naturales.

Todas estas políticas confluyeron en el surgimiento de un nuevo ciclo extractivo-exportador que, rompiendo con casi medio siglo de tradición mercado-internista, se independizaría casi por completo de las necesidades socioeconómicas domésticas para articularse exclusivamente en función de las exigencias del mercado mundial. Como resultado, la última década del siglo XX se convirtió en escenario de la implantación en el país de actividades extractivas ligadas al agronegocio (soja transgénica y, en menor medida, maíz, arroz y girasol), los hidrocarburos (petróleo, gas natural), la minería metalífera (oro, plata, cobre, hierro, plomo, litio, etc.), la depredación pesquera y la industria forestal (madera, pasta de celulosa). 
Esto obedeció a los cambios estructurales llevados a cabo tanto en la legislación nacional (nueva Ley de inversiones extranjeras de 1993, que dispuso la igualdad de trato de las actividades de compañías foráneas respecto de las empresas nacionales) como sectorial (desregulación casi total del sector agropecuario, aprobación de las primeras semillas transgénicas, sanción del nuevo Código de Minería, ventajas fiscales, comerciales y financieras, concesión de yacimientos metalíferos y áreas hidrocarburíferas, privatización de la petrolera estatal) (Frechero, 2013). Todos estos procesos se desarrollaron en el marco de un ciclo global de caída general de los precios internacionales de commodities, favoreciendo dentro del programa de concesiones y privatizaciones la apropiación y extranjerización a bajo costo de las reservas nacionales de hidrocarburos, minerales y tierras.

A comienzos del siglo XXI, la profunda pérdida de legitimidad y la crisis socio-política del neoliberalismo decantaron en una fase histórica híbrida y contradictoria: por un lado, la balanza se inclinaría ideológicamente hacia las políticas posneoliberales de los gobiernos autoproclamados progresistas (2002-2015); pero por otro lado, gran parte de las reformas estructurales heredadas del modelo neoliberal permanecerían intactas, afianzándose e incluso profundizándose. Otrora regresivas y garantistas, las reformas neoliberales fueron parcialmente suplantadas por políticas públicas activas de reindustrialización, control del movimiento de capitales financieros y movilidad social ascendente. Sin embargo, el neodesarrollismo argentino se erigió sobre las bases legadas por el neoliberalismo y la estrategia de reproducción de la nueva clase hegemónica nacida de dicho modelo (Féliz, 2012), la cual no se empeñó en revertir las consecuencias sociales, políticas y económicas de aquel, sino que las capitalizó en beneficio propio. La ruptura del régimen de convertibilidad y la devaluación monetaria centralizaron aún más el ingreso en los grupos exportadores de commodities, en tanto que la imposición de un régimen de retenciones permitió al Estado captar parte de la renta exportadora y -en teoría- canalizarla hacia sectores populares sin atenuar la concentración/extranjerización económica ni la depredación de los bienes naturales (Cortese, del C. Llano y equipo, 2013).

En materia de comercio internacional e inversión foránea, el Estado nacional continuó apostando a un estilo de desarrollo tan extrovertido y aperturista como el de antaño. La economía argentina abandonó (parcialmente) su subordinación respecto de Estados Unidos y Europa para suplantarla por la dependencia de China, pasando a desempeñar el doble rol de proveedor de materias primas y alimentos, y receptor de las inversiones e importaciones industriales del país oriental. Como resultado, el modelo primario exportador legado por el neoliberalismo se intensificó: soja, minerales metalíferos e hidrocarburos pasaron a alimentar el meteórico crecimiento del gigante asiático; paralelamente, se multiplicaron las inversiones de este último en ramas extractivas (petróleo, minería), infraestructura (ferrocarriles, puertos), sector financiero (bancos) y acaparamiento de tierras para cultivo. En el marco de la nueva división internacional del trabajo, la dependencia de Argentina respecto de China se tornó tan extrema que, para Lauffer (2009), constituiría una reedición de la antigua relación especial que el país mantuviera a finales del siglo XIX con Inglaterra.

Contrariamente a lo ocurrido durante la fase neoliberal, el modelo extractivista neodesarrollista se desplegó al compás del ciclo internacional de alza de los precios de commodities surgido durante la década de 2000 y consolidado luego del estallido de la burbuja financiero-inmobiliaria estadounidense. Otrora antagónicos y contradictorios, extractivismo y desarrollo se tornaron discursivamente complementarios, forjando un metarrelato emancipatorio donde la 'nueva' dinámica de acumulación primaria exportadora, la mayor intervención estatal y las políticas de movilidad social ascendente serían la llave del crecimiento económico, la estabilidad política y la redistribución del ingreso (Svampa, 2011; Burchardt \& Dietz, 2014). Sin embargo, la continuidad de las normas que definieron el modelo neoliberal de atracción de capitales y el creciente dinamismo del sector extractivo donde la IED creció $43 \%$ solo entre 2004 y 2010 , con incrementos sin parangón como los de la minería (297\%) y el sector agropecuario (159\%), sugieren que el renovado flujo de inversiones 
Modelo extractivo en Argentina (1990-2016): ¿del extractivismo clásico neoliberal al neoextractivismo progresista? Tres estudios de caso

registrado entre 2001 y 2010 fue la fase B de la oleada de capitales foráneos iniciada durante la década de 1990 (Frechero, 2013).

Asimismo, el comercio exterior argentino ha sufrido una fuerte reprimarización entre finales del modelo neoliberal y el apogeo de la fase neodesarrollista. En consonancia con lo que ocurrió en la mayoría de los países de América Latina, el peso de las ramas primario extractivas sobre las exportaciones pasó de $67,4 \%$ en 2001 a $68,5 \%$ en 2011 , llegando a un pico de 71,2\% en 2004 (Cepal, 2012, citado por Teubal y Palmisano, 2015) (Tabla 1). En ese contexto, nueve de las diez principales empresas exportadoras comercializaban commodities agrarios, mineros y petroleros (Frechero, 2013). Datos más recientes correspondientes a 2016 demuestran que dicha reprimarización aumentó, dado que $72,5 \%$ de las exportaciones correspondía a sectores basados en la explotación/elaboración de recursos naturales (Tabla 2). Nueve de los primeros diez complejos exportadores eran netamente primario extractivos, sobresaliendo el oleaginoso (33,5\%), el cerealero (13,2\%), el aurífero-cuprífero ( $4,6 \%)$, el bovino ( $4,5 \%$ ), el petrolero-petroquímico $(4,4 \%)$ y el pesquero (2,9\%) (MH-INDEC, 2017).

\section{El modelo extractivo en la Argentina actual: ¿pasaje al neoextractivismo progresista 0 continuidad del extractivismo neoliberal? Usos del territorio y ejemplos empíricos}

\subsection{Agronegocio, modelo sojero y las paradojas del neoextractivismo progresista}

Debido a las reformas neoliberales, el sector agropecuario argentino se convirtió en uno de los más desregulados del mundo (Teubal y Rodríguez, 2002). La eliminación total de los impuestos a las exportaciones permitió que más de $90 \%$ de la producción se volcara al mercado mundial, la supresión de los aranceles a la importación de bienes de capital alentó la renovación del parque de maquinarias y la estructura de costos de las explotaciones agropecuarias mutó al compás
Tabla 1. Participación del sector primario extractivo en las exportaciones latinoamericanas. Países y años seleccionados (2001-2011)

\begin{tabular}{c|c|c|c|c}
\hline País & 2001 & 2004 & 2007 & 2011 \\
\hline Argentina & 67,4 & 71,2 & 69,1 & 68,5 \\
Bolivia & 79,4 & 86,7 & 91,9 & 95,5 \\
Brasil & 46,0 & 47,0 & 51,7 & 66,2 \\
Chile & 82,2 & 86,8 & 89,6 & 89,2 \\
Colombia & 60,6 & 62,9 & 60,8 & 82,5 \\
Ecuador & 88,1 & 90,7 & 90,2 & 92 \\
México & 14,9 & 20,2 & 25,0 & 29,3 \\
Paraguay & 83,7 & 87,3 & 89,1 & 89,3 \\
Perú & 81,4 & 83,1 & 87,6 & 89,3 \\
Uruguay & 58,4 & 68,4 & 68,9 & s/d \\
Venezuela & 88,8 & 86,9 & 91,3 & 95,5 \\
\hline
\end{tabular}

Fuente: elaboración propia sobre la base de CEPAL (2012, citado por Teubal y Palmisano, 2015).

de la privatización de servicios, la retracción del crédito público, los altos costos financieros de la banca privada, la desaparición de entes reguladores (Junta Nacional de Granos, Corporación Nacional de Productores de Carnes), la concesión de puertos y la eliminación de los precios mínimos/ máximos y cupos de siembra, cosecha $y$ comercialización propios de la fase anterior. El resultado fue el surgimiento y consolidación del agronegocio, basado en la creciente concentración, centralización y extranjerización de tierras y capital, la profundización de la integración vertical agroindustrial, la penetración del "supermercadismo", el fin de la rotación ganadería/ agricultura y la irrupción del capital financiero.

El nuevo patrón de acumulación del sector rural en el país se desarrolló a expensas de la ganadería (masiva liquidación de vientres, retracción del área pecuaria, reducción del hato ganadero y el número de tambos) y los cultivos tradicionales pampeanos (avena, cebada, alpiste, mijo, lino, trigo, girasol) y extrapampeanos (caña de azúcar, algodón), cuya superficie retrocedió significativamente. En contraste, la frontera agrícola se expandió aceleradamente en el caso de las producciones extensivas de arroz, maíz ${ }^{3}$ y, sobre todo, soja. Según cifras oficiales

3 Entre las campañas agrícolas 1990/91 y 2015/2016, el área 
(Minagri, 2016), entre 1989/1990 y 2015/2016, la superficie sojera pasó de 5.073.000 a 20.602.542 hectáreas y su producción granaria trepó de 10.671 .100 a $58.800 .498 \mathrm{t}$, de lo cual se desprende que ambas aumentaron $306,1 \%$ y $451 \%$, respectivamente (Tabla 3 ).

Como resultado, este cultivo actualmente acapara casi $60 \%$ del área nacional sembrada con granos, representando $93,2 \%$ de la producción de cereales y oleaginosas, y $88,1 \%$ y $95,7 \%$ de la elaboración de

cultivada de arroz aumentó $118,1 \%$ (pasó de 98.000 a 214.750 ha), y la de maíz, 179,4\% (de 2.159.700 a 6.034.480 ha) (Minagri, 2016).

Tabla 2. Complejos intensivos en recursos naturales, según actividades económicas, valor exportado y participación en las exportaciones. Argentina, 2016

\begin{tabular}{l|c|c}
\hline \multicolumn{1}{c|}{ Complejo exportador } & Valor (millones de U\$S) & \% \\
\hline Complejo agroindustrial & 30.430 & 54,8 \\
- Oleaginoso (*) & 18.149 & 33,5 \\
- Cerealero & 7.611 & 13,2 \\
- Fruti-hortícola & 2.230 & 3,9 \\
- Uva & 991 & 1,7 \\
- Maní & 927 & 1,6 \\
- Tabacalero & 397 & 0,7 \\
- Algodonero & 125 & 0,2 \\
Complejo ganadero & 2.834 & 4,9 \\
- Bovino & 2.593 & 4,5 \\
- Ovino & 241 & 0,4 \\
Complejo forestal & 513 & 0,9 \\
Complejo minero metalifero & 2.689 & 4,6 \\
- Oro & 2.045 & 3,5 \\
- Cobre & 644 & 1,1 \\
Complejo petrolero-petroquímico & 2.539 & 4,4 \\
Complejo pesquero & 1.699 & 2,9 \\
Sub-total complejos extractivos & $\mathbf{3 8 . 2 0 9}$ & $\mathbf{7 2 , 5}$ \\
Otros complejos exportadores & 15.790 & $\mathbf{2 7 , 5}$ \\
Complejo automotriz & 5.527 & 9,6 \\
Complejo farmacéutico & 906 & 1,6 \\
Complejo aluminio & 597 & 1,0 \\
Complejo siderúrgico & 455 & 0,8 \\
Resto & 8.305 & $\mathbf{1 0 0 , 0}$ \\
Total & $\mathbf{5 7 . 7 3 3}$ & \\
\hline
\end{tabular}

Fuente: elaboración propia sobre la base de MH-INDEC (2017).

Tabla 3. Cultivo de soja en Argentina. Superficie sembrada y producción granaria, años seleccionados (campañas agrícolas 1989/90-2015/16)

\begin{tabular}{l|c|c}
\hline Campaña agrícola & Superficie sembrada (hectáreas) & Producción granaria (toneladas) \\
\hline $1989 / 90$ & 5.073 .000 & 10.671 .100 \\
$1996 / 97$ & 6.669 .500 & 11.004 .890 \\
$2002 / 03$ & 12.606 .845 & 34.818 .550 \\
$2008 / 09$ & 18.042 .895 & 30.989 .469 \\
$2015 / 16$ & 20.602 .542 & 58.800 .498 \\
Variación 1989/90-2015/16 & $306,1 \%$ & $451,0 \%$ \\
\hline
\end{tabular}

Fuente: elaboración propia sobre la base de Minagri (2016). 
aceites y harinas, respectivamente (Ciara, 2016). Así, Argentina se convirtió en el tercer productor y exportador mundial de granos de soja después de Estados Unidos y Brasil, y en el primer exportador de harinas y aceites de dicha oleaginosa (Giancola, Salvador Covacevich e Iturrioz, 2009). Las exportaciones absorben el $95 \%$ de la producción sojera, destinándose sobre todo a China, India y la Unión Europea, y en menor medida a Pakistán, Bangladesh y Japón (Pierri, 2006; Giancola et al., 2009; Teubal y Palmisano, 2013).

Otrora exclusivamente circunscrito a la región pampeana, a partir de finales de la década de 1990 el modelo fue trasplantado a provincias extrapampeanas de la mano de diversos factores como el cambio del régimen de lluvias, el sostenido aumento de los precios y la demanda internacional, la introducción de variedades transgénicas resistentes a herbicidas, la tecnificación del trabajo agropecuario (siembra directa, riego mecanizado e informatizado, uso intensivo de pesticidas y fertilizantes), el bajo valor de la tierra, el surgimiento de megaempresas agropecuarias y pools de siembra, la crisis financiera de 2008 que desplazó capitales especulativos hacia los mercados de commodities, y el boom de los agrocombustibles. Los grandes traders granarios y las agroindustrias aceiteras nacionales (Aceitera General Deheza, Molinos Cañuelas, Vicentín, Molinos Río de la Plata) y extranjeras (Cargill, Louis Dreyfus, Glencore, Bunge, Noble, Nidera, Cofco) desempeñaron un rol clave en la sojización del centro y norte del país, demandando crecientes volúmenes de materia prima y desarrollando estrategias de integración vertical hacia distintos eslabones de la cadena (agricultura, transporte ferro-portuario).

Como resultado, el agronegocio se ha configurado en el principal motor de la inserción de la economía argentina en el mercado mundial. Impulsadas por la fiebre sojera, las oleaginosas y sus derivados actualmente constituyen el primer complejo exportador del país, acaparando el $33,5 \%$ de las exportaciones nacionales. Otrora principal rubro exportable del país, los cereales fueron desplazados al segundo lugar $(13,2 \%$ del total), en tanto que la ganadería bovina, relegada a áreas marginales y reconvertida a sistemas intensivos o feed-lots, redujo su incidencia general al 4,5\% (MH-INDEC, 2017).

Las consecuencias socioeconómicas, ambientales y sanitarias del extractivismo sojero han sido catastróficas: endeudamiento financiero de pequeños y medianos productores; masivos remates e hipotecas bancarias; desaparición de $32,9 \%$ de las explotaciones agropecuarias en veinte años (1988-2008); avasallamiento de derechos políticos y sociales debido a la usurpación violenta de tierras; arrinconamiento, expulsión y asesinato de pequeños agricultores capitalistas, campesinos y aborígenes; deforestación de bosques nativos, con tasas anuales de desmonte muy superiores a la media mundial; crecientes niveles de erosión, emisión de gases invernadero, pérdida de biodiversidad y expoliación de nutrientes edáficos y recursos hídricos; aumento de la frecuencia y gravedad de inundaciones, aludes y deslizamientos; proliferación de nacimientos con malformaciones y patologías respiratorias, digestivas, endocrinas, neurológicas, reproductivas y oncológicas asociadas a las fumigaciones con agrotóxicos4; y subordinación de los agricultores a las estrategias de acumulación de corporaciones transnacionales semilleras y agroquímicas como Monsanto, Bayer, Dow, Syngenta, BASF y Nidera. Aunque a mucha menor escala, el saldo de la expansión de la frontera agrícola ligada al maíz y el arroz ha sido igualmente calamitoso, operando como vector secundario del extractivismo agrícola intrínseco al modelo sojero.

Obstando la sanción de normas puntuales como la Ley de Bosques, que a partir de 2009 limitó los desmontes y el desarrollo de conflictos puntuales asociados a los derechos de propiedad intelectual sobre semillas, el Estado neodesarrollista se ha mostrado

4 Por ejemplo, glifosato de amonio, cipermetrina, clorpirifós, paraquat, malathión, 2,4-D, endosulfán, hexaclorobenceno, heptacloro y atrazina. 
tan consustanciado con el modelo de agronegocios como lo estuvo durante la década neoliberal. La frontera agrícola siguió expandiéndose sin pausa, tanto los puertos como los servicios públicos vinculados al sector continuaron en manos privadas -y a menudo, extranjeras-, la vocación netamente exportadora de la producción granaria, cárnica y agroindustrial se agudizó, la concentración y extranjerización de la tierra recrudecieron notablemente, la tecnificación (y vaciamiento demográfico) del campo se profundizaron y el Estado aprobó tanto nuevas variedades transgénicas de maíz, soja y algodón resistentes a plagas y herbicidas como un creciente número de productos agrotóxicos ${ }^{5}$. Continuaron, asimismo, las políticas de subordinación ante los intereses de las compañías biotecnológicas en detrimento de los agricultores ${ }^{6} \mathrm{y}$ uso del aparato jurídico-represivo del Estado al servicio de las empresas sojeras para así garantizar el despojo de tierras y el avance de la deforestación en gran parte del país.

Lo que sin duda representó un punto de inflexión respecto del papel estatal en la dinámica

5 En 1996 solo existía un cultivo transgénico en la Argentina: la soja RR, resistente al herbicida glifosato de amonio. A finales de 2015 , el número se elevaba a 36 -de los cuales la inmensa mayoría fue aprobada entre 2002 y 2015-, mientras que los pesticidas ya contaban con 4.478 formulaciones comerciales aprobadas, a un ritmo de ingreso al mercado de casi 120 productos anuales (Sández, 2016).

6 En 1999, contraviniendo la ley argentina de semillas, el Estado nacional permitió a Nidera y otras licenciatarias de Monsanto imponer un sistema de "regalías extendidas", según el cual la adquisición de la semilla de soja RR implicaba la automática adhesión del agricultor a un contrato que les impedía guardar y/o compartir su cosecha y lo obligaba a pagar 2 dólares -más impuestos- por cada bolsa de $50 \mathrm{~kg}$ de semillas implantada durante la siguiente campaña agrícola. En 2012, Monsanto patentó la soja RR2 Intacta Pro -tolerante a glifosato y resistente a plagas de insectos- y estipuló que esta sólo podía ser adquirida por productores que firmaran un contrato de licencia donde aceptaran pagar "regalías extendidas" al momento de la compra. El Estado nacional operó como garante de los derechos de propiedad intelectual de la compañía confirmando la validez de los contratos, comprometiéndose a sancionar una nueva ley de semillas favorable a los intereses de Monsanto, y contribuyendo a fiscalizar la procedencia (legal o ilegal) de la simiente usada por los productores sojeros. de acumulación del sector agropecuario fue su creciente participación en la captación y redistribución de la renta exportadora. Luego de la salida del Régimen de Convertibilidad y la devaluación de la moneda nacional, el gobierno argentino restableció la aplicación de derechos de exportación (retenciones) a la producción agropecuaria y otros bienes primarios como mecanismo para reducir el impacto de los precios en la canasta básica de consumo y también como forma de recaudación fiscal y financiamiento del Estado ante el boom de los precios internacionales de los commodities (Palma y Cantamutto, 2016). Al comienzo oscilando entre el $5 \%$ y el $10 \%$ de las exportaciones de oleaginosas, cereales y carnes en general (sin discriminar entre subproductos), estos aranceles aumentaron a lo largo del período hasta alcanzar $13 \%$ para la harina de trigo, $28 \%$ para el trigo en grano, $25 \%$ para el maíz, entre $30 \%$ y $32 \%$ para el girasol y sus derivados, $32 \%$ para los aceites y harinas de soja y $35 \%$ para la soja sin procesar.

En 2008, el Estado procuró ampliar su participación en la renta agroexportadora implementando un régimen de retenciones móviles según la variación de los precios internacionales, lo cual le hubiese permitido apropiarse del $39 \%$ y el $41 \%$ de la renta exportadora del girasol y la soja, respectivamente. Sin embargo, esta política fracasó al ser duramente resistida por los productores agropecuarios y desencadenar uno de los paros agrarios más largos y complejos de la historia argentina (Palmisano, 2014), determinando que desde entonces el gobierno nacional mantuviera una relación contradictoria de alianza y enfrentamiento con los agricultores sojeros (Cortese et al., 2013).

Si bien la cadena agroindustrial representa aproximadamente el $49 \%$ de la recaudación de los derechos de exportación percibidos por el Estado (Porto, 2009), es importante relativizar su importancia. Aunque los defensores del modelo sojero arguyan que la apropiación pública de parte de la renta sojera es clave para que el Estado resuelva desequilibrios comerciales, sostenga las cuentas fiscales, pague puntualmente los intereses de la deuda externa y efectúe políticas de redistribución del ingreso a través de obras de 
Modelo extractivo en Argentina (1990-2016): ¿del extractivismo clásico neoliberal al neoextractivismo progresista? Tres estudios de caso

\begin{tabular}{c|c|c|c|c|c}
\hline \multicolumn{5}{c}{ Tabla 4. Principales fuentes de recaudación fiscal (en \%), Argentina, años seleccionados 2002-2011 } \\
\hline Año & $\begin{array}{c}\text { Impuesto al } \\
\text { Valor Agregado }\end{array}$ & $\begin{array}{c}\text { Impuesto a las } \\
\text { Ganancias }\end{array}$ & Seguridad social & $\begin{array}{c}\text { Derechos de exportación al } \\
\text { complejo agropecuario }\end{array}$ & $\begin{array}{c}\text { Otros recursos } \\
\text { aduaneros }\end{array}$ \\
\hline 2002 & 27,34 & 16,00 & 24,17 & $\mathbf{4 , 9 7}$ & 6,44 \\
2003 & 26,41 & 18,6 & 20,96 & $\mathbf{8 , 2 1}$ & 6,37 \\
2007 & 28,00 & 19,00 & 25,28 & $\mathbf{6 , 3 2}$ & 6,65 \\
2008 & 27,00 & 18,00 & 26,40 & $\mathbf{7 , 8 4}$ & 7,76 \\
2011 & 26,00 & 19,00 & 30,16 & $\mathbf{6 , 1 4}$ & 6,17 \\
\hline
\end{tabular}

Fuente: elaboración propia sobre la base de Palmisano (2014).

infraestructura, asistencia social y control de precios en el mercado interno, lo cierto es que los derechos impuestos a los complejos oleaginoso, cerealero y vacuno representaron en 2011 apenas el $6,17 \%$ de la recaudación fiscal nacional, no habiendo jamás superado la barrera del 8,21\% (Tabla 4). Así, las retenciones como mecanismo de captación del excedente representan un magro aporte a la masa de ingresos fiscales del Estado, reducido a su vez por los intrincados mecanismos de liquidación del arancel (Palmisano, 2014).

Si bien la participación estatal en la renta ha aumentado en términos relativos, la devaluación primero y el alza de los precios internacionales después redujeron los costos domésticos y multiplicaron los beneficios de productores agropecuarios y agroindustrias ${ }^{7}$, reforzando la concentración del ingreso en pocas manos. En el caso del sector agropecuario, el impacto de las retenciones fue mucho menor al de la modificación del tipo de cambio, incrementando sus ganancias, especialmente en los estratos más concentrados del capital (Palma y Cantamutto, 2016). Como resultado, la reinstauración de los derechos de exportación no impidió que las nuevas políticas monetarias efectuaran una redistribución de la renta agraria a favor del sector, lo cual potenció el avance del agronegocio (Palmisano, 2014).

7 Entre 2002 y 2015, la relación cambiaria entre la divisa norteamericana y la moneda nacional pasó de 1,40 pesos por dólar a 9 pesos por dólar. A esto debe añadirse el importante aumento de las cotizaciones internacionales de los principales commodities agrícolas entre 2002 y 2012, especialmente la soja, cuyo valor trepó de 270 a 640 dólares.
Por añadidura, parte del excedente captado por el Estado nacional en concepto de derechos de exportación retornó a molinos, cerealeras, aceiteras y otras firmas agroindustriales bajo la forma de subsidios orientados a resarcir a estas empresas por mantener los precios de alimentos básicos en el mercado interno por debajo de las cotizaciones internacionales. Solo entre 2007 y 2010 el gobierno argentino canalizó más de 9.000 millones de pesos a agroindustrias con aceitados vínculos políticos con la gestión como Cargill, Nidera, Grobocopatel, Molinos Río de la Plata, Aceitera General Deheza y Molinos Cañuelas, las cuales cumplieron parcialmente con el compromiso de mantener los precios de sus productos en el mercado nacional e incluso desplegaron fraudulentas operaciones de triangulación para exportar harina y aceite utilizando el incentivo estatal (Montenegro, 2011). A lo anterior deberían añadirse los generosos créditos públicos otorgados a partir de 2010 a estas firmas para ampliar su capacidad instalada de producción y almacenamiento (Paulinovich, 2013). Como resultado, y contrariamente a lo que postula Gudynas (2009), este esquema regulatorio estatal más activo pareció orientarse a favorecer exclusivamente a los "amigos" del poder político.

Otro ejemplo de esa lógica fue la intervención estatal en el mercado granario a partir de la creación en 2008 de la Organización Nacional de Comercialización de Cereales en la Argentina (ONCCA). Orientada en principio a fiscalizar y auditar a los operadores granarios, penalizar prácticas desleales e instrumentar mecanismos compensatorios para el sector agroalimentario, la ONCCA distribuyó discrecionalmente cupos 
exportables entre ciertas empresas bajo la fachada del Estado y su supuesta disputa con los agentes agroindustriales más concentrados. Sobresalió aquí el otorgamiento en 2013 de $26 \%$ del multimillonario cupo de exportación de maíz a la Cámara de Exportadores de Cereales y Oleaginosas (Capeco), una entidad creada y controlada directamente por el propio gobierno para competir con las transnacionales norteamericanas y europeas nucleadas en la Cámara de la Industria Aceitera de la República Argentina (Ciara). Si bien el discurso estatal argüía que la fundación de Capeco favorecería a cooperativas agrarias y pequeñas cerealeras, la entidad pasó rápidamente a albergar a grandes empresas argentinas (Aceitera General Deheza, UPJ-Los Grobo, ACA), brasileñas (Multigrain) y estadounidenses (Monsanto, CHS) con fluida relación con el gobierno, proceso estrechamente monitoreado y alentado desde el exterior por China (Paulinovich, 2013).

Independientemente de la limitada captación estatal de parte de la renta agroexportadora y la erosión de una porción de ese excedente debido a las políticas públicas de subsidio directo e indirecto a los agentes privilegiados del agronegocio, lo cierto es que la recaudación de derechos de exportación ha abonado el mito neodesarrollista respecto del papel del extractivismo agrícola -y sobre todo sojerocomo fuente de recursos para el financiamiento de programas asistencialistas y la reducción de la pobreza. Sin embargo, esa contribución a la fábula fue más discursiva que real. Aunque algunas políticas de redistribución del ingreso (Plan Jefes y Jefas de Hogar, Asignación Universal por Hijo, transferencias de seguridad social, ampliación de la cobertura previsional) contribuyeron a la disminución de la pobreza por ingresos, las cifras oficiales (según las cuales entre 2003 y 2013 la incidencia de este flagelo se redujo del $54 \%$ al $4,7 \%$ de la población) (INDEC, 2014) perdieron credibilidad debido a la intervención gubernamental en 2008 del organismo estatal que mide la inflación. Voces críticas y estudios independientes han denunciado que el poder político manipula fraudulentamente las mediciones de precios para así subestimar la pobreza, calculando una tasa promedio general (36,5\%) casi ocho veces superior a la oficial (Rameri, Haimovich, Lozano y Raffo, 2014).

Independientemente de la gigantesca catástrofe social (desplazamiento de aborígenes y campesinos, éxodo rural, migración compulsiva a las periferias urbanas, etc.) desatada por el modelo extractivo ${ }^{8}$, también se ha puesto en tela de juicio el impacto que las retenciones sojeras habrían tenido sobre el desarrollo regional. Compuesto por la federalización a provincias y municipios del $30 \%$ de la recaudación de los derechos de exportación de soja y subproductos, el Fondo Federal Solidario (FFS) fue implementado a partir de 2009 para financiar obras de mejora de la infraestructura sanitaria, educativa, de vivienda y vial. Aunque informes oficiales difundidos por la prensa destaquen que el FFS viabilizó el 32\% de la obra pública realizada durante los últimos años (Página 12, 2015), las acuciantes necesidades presupuestarias provinciales y municipales suelen implicar que dichos recursos se utilicen para pagar salarios de empleados públicos ( $\mathrm{La}$ Política Online, 2013).

\subsection{La pesca marítima y la continuidad del extractivismo neoliberal}

Con epicentro en el litoral bonaerense y patagónico, la pesca marítima tampoco ha sido ajena a la aguda reestructuración neoliberal de la década de 1990. Ignorando los incipientes síntomas de sobreexplotación del recurso, el gobierno argentino desarrolló dos políticas de apertura y extranjerización del sector: los permisos otorgados a armadores argentinos para arrendar a casco desnudo buques poteros españoles y coreanos para la captura del calamar; y la implementación en 1994 del Acuerdo sobre las relaciones en materia de pesca entre la República Argentina y la Comunidad Económica

8 Paradójicamente, el Estado nacional dispuso en 2008 que $2 \%$ de las retenciones a las exportaciones agrícolas, ganaderas y forestales fuera destinado a financiar el Fondo Nacional para el Enriquecimiento y la Conservación de los Bosques Nativos. 
Europea, que permitió el masivo ingreso de la flota española al caladero nacional. En ese marco, el Estado fomentó la fusión entre firmas pesqueras europeas y nacionales a través de asociaciones temporales de empresas y sociedades mixtas, permitiendo también operaciones individuales de buques comunitarios y radicaciones empresariales. Según Muleiro (2000), Argentina absorbió el 44\% de los buques de gran tonelaje transferidos por España a otros países durante la década de 1990.

Conforme al acuerdo, las operaciones de pesca debían realizarse utilizando licencias o permisos ya emitidos, lo cual hacía posible su transferencia entre armadores argentinos y europeos a través de un régimen de charter subsidiado por la propia Comunidad Económica Europea (CEE), principal destino del pescado extraído en aguas argentinas. El Estado nacional también subsidiaba la flota congeladora extranjera, beneficiándola con reintegros fiscales para exportaciones pesqueras por puertos patagónicos, lo cual alentaba a las firmas 'mixtas' a presentar sobrefacturaciones para acceder a un mayor caudal de recursos públicos. Amén de avasallar la legislación vigente que disponía la reserva exclusiva del recurso para embarcaciones de pabellón nacional, este proceso legitimó el desarrollo de diversas prácticas predatorias como el ingreso de buques cuya capacidad de extracción duplicaba la de los barcos cedentes, la reiterada ampliación de los cupos iniciales de captura otorgados por el Estado y la utilización de artes de pesca de mayor capacidad de captura, propiciando el surgimiento de lo que Cóccaro, Le Bail, Gómez y Boetto (2000) llaman un 'mercado flotante de permisos de pesca', donde las licencias y sus respectivas cuotas de extracción se multiplicaban mediante mecanismos ilegales (Fratini, 2006, p. 138).

Las consecuencias no se hicieron esperar: en 1997 el sector alcanzó su máximo histórico de capturas, alcanzando 1.343.220 t superando en un $166,9 \%$ los desembarques de 1989 (DEP, 2016a) y llegando incluso a rebasar las exportaciones de carne bovina (Fratini, 2006). Al compás de la sobreexplotación de las diferentes variedades de merluza, el calamar, la polaca y la corvina, los elevados niveles de sobrepesca (más del $250 \%$ ) y la escasez de la merluza como principal especie-objetivo (cuyas reservas disminuyeron $75 \%$, con una reducción de biomasa de $28 \%$ y una capacidad reproductiva inferior a $30 \%$ ) (INAP, 1999; FVSA, 2008) determinaron que tres años después el volumen general de capturas se desplomara un 36,2\% (DEP, 2016a) y el sector se sumergiera en una aguda crisis.

En pleno apogeo neoliberal, la calamitosa situación del caladero argentino obligó al Estado a intervenir en el sector declarando la Emergencia Pesquera Nacional, poniendo fin al convenio con la CEE, imponiendo estrictos cupos de captura a la flota fresquera y decretando la veda total para la pesca de merluza para la flota congeladora y factoría extranjera, que quedó relegada al sur del paralelo $48^{\circ} \mathrm{S}$ y fuera de la Zona Económica Exclusiva (ZEE). No obstante, esa última política afectó solo parcialmente los intereses de los grandes grupos económicos de la pesca, que poseen buques fresqueros y congeladores que operan simultáneamente en el litoral bonaerense y patagónico. Ante la escasez de merluza común, las empresas se volcaron masivamente hacia el calamar que se hallaba exento de restricciones, en tanto que el Estado permitía en plena crisis pesquera el ingreso a aguas argentinas de 27 barcos poteros japoneses mediante un nuevo régimen de licencias (charter) que concedía un cupo de extracción de 65 millones de dólares a cambio del pago de un canon de solo 5,5 millones de dólares. Además de intensificar la presión sobre el recurso, esa política agravó la crisis de la merluza común, dado que el calamar es uno de sus principales alimentos.

Paradójicamente, el advenimiento de gobiernos "progresistas" críticos de la experiencia neoliberal implicó que la racionalidad pesquera extractivista y depredadora a ultranza continuara e incluso se agudizara, siempre de la mano del capital privado y la flota extranjera. Destinado a impedir el ingreso de buques pesqueros a áreas vedadas, el Sistema de Monitoreo Pesquero Satelital (MONPESAT) fue desactivado en 2002, 


\begin{tabular}{|c|c|c|c|c|}
\hline Puerto pesquero & Reintegro 1995 & Reintegro 2006 & Reintegro 2015 & Derechos pesqueros de exportación 2005-2015 \\
\hline Puerto Madryn & $8 \%$ & $0 \%$ & $8 \%$ & $5 \%-10 \%$ \\
\hline Comodoro Rivadavia & $9 \%$ & $0 \%$ & $9 \%$ & $5 \%-10 \%$ \\
\hline Rawson & $9 \%$ & $0 \%$ & $9 \%$ & $5 \%-10 \%$ \\
\hline Puerto Deseado & $11 \%$ & $0 \%$ & $11 \%$ & $5 \%-10 \%$ \\
\hline Punta Quilla & $12 \%$ & $0 \%$ & $12 \%$ & $5 \%-10 \%$ \\
\hline Río Gallegos & $12 \%$ & $0 \%$ & $12 \%$ & $5 \%-10 \%$ \\
\hline Ushuaia & $13 \%$ & $0 \%$ & $13 \%$ & $5 \%-10 \%$ \\
\hline
\end{tabular}

Fuente: elaboración propia.

siendo reemplazado por sistemas de control más precarios como la vigilancia con cámaras de seguridad aportadas por las propias empresas pesqueras, el control aéreo de la Armada Argentina, la presencia de observadores a bordo y las inspecciones en los puertos de desembarque desarrolladas en un marco de carencia del equipamiento más elemental (balanzas, softwares adecuados, herramientas para el control de la talla de los peces, etc.). En 2004, el Estado nacional puso fin a la veda liberando de toda restricción a la flota congeladora, permitiéndole operar en el área adyacente a la Zona Económica Exclusiva (ZEE) y otorgándole además un cupo del 22\% sobre las capturas incidentales de merluza común. Paralelamente, el nivel de extranjerización de la flota pesquera de altura se acentuó, con predominio de buques españoles, rusos, chilenos, ingleses, panameños, coreanos, japoneses, noruegos, canadienses, neozelandeses, chinos y taiwaneses, formalmente comandados por un capitán argentino (como lo exige la ley) pero cuyas tareas de captura son irregularmente dirigidas por un tripulante extranjero (Osiroff, 2009).

Por añadidura, el Estado nacional implementó el sistema de cuotas individuales transferibles de captura (SCITC), consolidando bajo el paradigma neodesarrollista la reforma pesquera de la fase previa. Originalmente establecido en 1998 por la entonces flamante Ley Federal de Pesca a instancias de las usinas de pensamiento neoliberal, el SCITC comenzó a regir en Argentina en 2009, una vez apaciguados los conflictos generados por la escasez de merluza común y la veda para su captura. El SCITC otorga a cada buque de la flota una cuota porcentual sobre el cupo total máximo permisible correspondiente a cada especie (polaca, merluza común, de cola y negra) por un lapso de 15 años, basándose para ello en diferentes indicadores, especialmente en el promedio del historial de capturas durante el período 19891996. Como bien apunta Osiroff (2009), el SCITC ha creado un grupo de pescadores de elite cuyo historial predatorio sobre el recurso y contribución a la dramática reducción de la biomasa explotable no han sido penalizados sino premiados por el Estado. Permitiendo a las grandes empresas y flotas extranjeras apropiarse legalmente de una cuota del recurso, el SCITC profundizó la privatización y concentración legada por el neoliberalismo a tal punto que según cifras oficiales, en 2015 de 181 empresas apenas diez concentraban el $52 \%$ de las exportaciones pesqueras (DEP, 2016b).

No existió, tampoco, intervención directa por parte del Estado en el sector. Con gran peso relativo (76\%) de la merluza común, el calamar y el langostino (DEP, 2016b), en 2015 las exportaciones pesqueras representaron el $95 \%$ de la extracción global ${ }^{9}$ (DEP, 2016a), dando cuenta del 2,9\% del comercio exterior nacional (MH-INDEC, 2017). Sin embargo, el Estado no se apropió de una parte sustancial de la renta: de hecho, los derechos de exportación impuestos al sector fueron del $10 \%$ para el pescado congelado a bordo y del $5 \%$ para el pescado fresco procesado en tierra. Asimismo, los reintegros a las exportaciones

9 España, China, Estados Unidos, Japón, Italia y Brasil absorben $70 \%$ de las exportaciones pesqueras argentinas (DEP, 2016b). 
Modelo extractivo en Argentina (1990-2016):

¿del extractivismo clásico neoliberal al neoextractivismo progresista? Tres estudios de caso

por puertos patagónicos vigentes durante la fase neoliberal, que en 2006 habían sido eliminados, fueron restablecidos en 2015 en sus valores originales, con montos que oscilaban entre el $8 \%$ y el $13 \%$ del valor comercializado, licuando y/o directamente eliminando (según el caso) los magros ingresos estatales en concepto de retenciones (Tabla 5).

Finalmente, el recurso continuó siendo esquilmado hasta el umbral de la extinción. A raíz del excesivo esfuerzo de pesca, el número de ejemplares adultos de merluza común se redujo sustancialmente y, según cifras oficiales, el volumen general de capturas sufrió una importante caída, con desembarques un 10,5\% inferiores a los de 2000 (DEP, 2016a), año de la peor emergencia pesquera argentin $\mathrm{a}^{10}$. Sin embargo, el Estado continuó con su política de entrega de recursos pesqueros al capital extranjero, permitiendo en 2013 el ingreso a la ZEE de buques poteros chinos para la pesca de calamar por medio de un régimen charter muy similar al antiguo modelo que durante la década neoliberal privilegió la flota coreana y japonesa. A esto debe añadirse la pesca del langostino por parte de la flota española y de centollas y vieiras por parte de los buques estadounidenses y canadienses, la depredación uruguaya de corvinas y merluzas y las operaciones clandestinas de flotas furtivas en la ZEE.

\subsection{Narrativa neodesarrollista, Estado garantista: las contradicciones del extractivismo minero}

La minería metálica desempeñó un papel históricamente marginal en la construcción de la matriz primario extractiva exportadora argentina hasta la década de 1990, cuando las reformas neoliberales pergeñaron un andamiaje jurídico extremadamente favorable para la actividad. Oriundos de Australia, Canadá, Estados Unidos, Suiza, Inglaterra, Sudáfrica, Chile, Perú

10 En 2000 las capturas ascendieron a 857.369 t, retrocediendo a 692.071 t en 2012 y 767.694 t en 2015 (DEP, 2016a). y Japón, los flujos de IED minera en el país crecieron exponencialmente de 4 millones de dólares en 1992 a 2.350 millones en 2013 (MEyM, 2016a), azuzados por la reducción del nivel de reservas y ley mineral en sus naciones de origen, la creciente rigurosidad de las legislaciones ambientales de los países centrales, la constante demanda de oro para joyería y reserva monetaria, las crecientes importaciones chinas de cobre y la fiebre del litio. El número de proyectos pasó de 40 a 336, y el de empresas, de 7 a 157, con absoluta primacía (entre $85 \%$ y $97,5 \%$ ) de firmas extranjeras (MEyM, 2016a; Álvarez, 2017) como Glencore-Xtrata Copper, Anglogold-Ashanti, MCC, Barrick Gold, Yamana Gold, Pan American Silver, Goldcorp, McEwen Mining y Silver Standard Resources. Representando $80 \%$ de la extracción, las remesas argentinas de metales aumentaron $2.000 \%$ en veinte años (SM, 2008; CAEM, 2015), convirtiendo al sector en el sexto complejo exportador nacional. Seguidos por molibdeno, plomo, zinc, hierro y litio, los principales minerales exportados son oro, cobre y plata, en su mayoría (83\%) absorbidos por Suiza, Canadá y Alemania (MEyM, 2016a).

Sin perjuicio de lo anterior, la actividad se ha desarrollado a gran escala en sólo cuatro provincias: Jujuy (minas El Aguilar, Pirquitas y Salar de Olaroz); Catamarca (Bajo La Alumbrera y Salar del Hombre Muerto); San Juan (Veladero, Gualcamayo y Casposo); y Santa Cruz (Cerro Vanguardia, San José-Huevos Verdes, Manantial Espejo, Martha, Lomada de Leiva y Cerro Negro), con presencia puntual en Neuquén (Andacollo) y Río Negro (Sierra Grande). En todas esas provincias el saldo socioeconómico y ambiental del boom minero ha sido devastador: despojo y acaparamiento de tierras; excesivos niveles de especialización productiva; privatización, acaparamiento y agotamiento del recurso hídrico, con la consiguiente pérdida de cultivos, mortandad del ganado y escasez de agua para comunidades campesinas y aborígenes; pérdida de biodiversidad y desequilibrio de ecosistemas frágiles; desmesurado consumo energético; destrucción de recursos paisajísticos y afectación de viviendas; altísimos niveles de polución ambiental con compuestos químicos peligrosos y 
metales pesados; aparición de graves enfermedades entre la población local; y avasallamiento de derechos civiles y políticos vía asistencialismo, clientelismo, control y censura en medios de comunicación e instituciones educativas, espionaje, criminalización y judicialización de la protesta, represión y paramilitarización.

Lejos de expresar rupturas asociadas al cambio de signo político gubernamental, el papel del Estado ha sido invariable a lo largo del neoliberalismo y el neodesarrollismo: operar como garante de los intereses del empresariado transnacional, fijando controles acotados y casi no interviniendo en la captación y redistribución de la renta minera. Auxiliado por créditos del Banco Mundial, el gobierno nacional diseñó durante la década de 1990 un paquete de reformas normativas institucionales conformado por la Ley de Inversiones Mineras, la Ley de Reordenamiento Minero, el Acuerdo Federal Minero y la reformulación del Código de Minería. Esa nueva legislación contemplaba vastas ventajas fiscales, arancelarias, tributarias, comerciales, financieras, políticas y territoriales, como estabilidad fiscal por 30 años, desgravación de las importaciones de insumos y bienes de capital (arancel ०\%), reembolso del impuesto al valor agregado (IVA), doble deducción de costos de exploración, regalías provinciales del 3\% del valor extraído", eliminación de gravámenes y tasas municipales y exención del impuesto al cheque, a los sellos, a los combustibles y a la ganancia mínima presunta. El Tratado de Integración Minera firmado en 1994 entre Argentina y Chile selló la alianza estatal con el sector, convirtiendo la Cordillera de Los Andes en un "tercer país" independizado por cuarenta años de los respectivos gobiernos nacionales donde las empresas reclutan fuerza laboral, coordinan logística y transporte, y explotan el recurso hídrico.

Con el fin del modelo neoliberal, la minería metalífera fue ampliamente beneficiada por la

11 Asimismo, la normativa vigente permite que previamente a la liquidación de las regalías se sustraigan los costos de trituración, molienda, fundición, refinación, transporte, seguros y comercialización. reducción de costos ocasionada por la devaluación, pero no sufrió la retención de parte del excedente. Recién en 2007, cinco años después de que medidas similares fueran implementadas en otras ramas extractivas, el gobierno nacional intentó cobrar al sector derechos de exportación del $10 \%$ para el cobre y la plata y del $5 \%$ para el oro y el litio, pero las mineras extranjeras resistieron enconadamente la medida, ora pagando bajo protesto, ora interponiendo medidas cautelares que argüían que esa política violaba la estabilidad fiscal de sus inversiones. Durante la fase neodesarrollista, el Estado también preservó las generosas ventajas legadas por el neoliberalismo e incluso añadió otras nuevas, como permisos para exportar y remitir utilidades al exterior sin pagar impuestos y utilizar cuentas off shore como base para activos financieros y plazas de depósito para divisas, exención del IVA y el impuesto a créditos y débitos bancarios, deducción del impuesto a las ganancias y financiamiento del programa de gestión ambiental minera. Asimismo, el canon de concesión de áreas mineras cobrado a las empresas continuó siendo tan irrisorio como durante la fase neoliberal: 400 pesos por única vez para la explotación y 80 pesos anuales para la exploración (Basualdo, 2013).

Si bien la actividad se caracteriza por sus siderales niveles de rentabilidad ${ }^{12}$, el Estado no avanzó sobre la captación de la renta minera ni sobre la explotación directa del recurso. Respecto al primer punto, las corporaciones transnacionales suelen argüir que debido a la excesiva presión fiscal el Estado se apropia del $42 \%$ de la renta (CAEM, 2015); sin embargo, la realidad es muy diferente ${ }^{13}$. En tal sentido, Murguía (2015) realizó estimaciones respecto de la facturación, los costos de producción y la renta pública y

12 Entre 2005 y 2009, cuando ese indicador fue de "apenas" $10 \%$ para la cúpula empresarial argentina, las operadoras de Bajo La Alumbrera y Veladero obtuvieron tasas de ganancia del 47,5\% y 70,5\%, respectivamente (Basualdo, 2013).

13 Tales estimaciones se sustentan en falsedades como afirmar que las mineras erogan los mismos impuestos que el resto de las actividades económicas (CAEM, 2015), cuando en realidad la legislación vigente exime sus inversiones y utilidades del pago de tales tributos. 
privada correspondiente a los principales yacimientos en actividad, de las cuales se desprende que los recursos fiscales extraídos del sector durante el período 1997-2012 habrían representado el 25,64\% de la facturación. De hecho, a raíz de su política de exenciones fiscales y aduaneras entre 1997 y 2012, el Estado dejó de percibir ingresos por 6.000 millones de dólares y puso en juego 25.000 millones (Murguía, 2015).

Sobre la base de los datos aportados por este autor, si se analiza el caso de las dos principales minas metalíferas del país (Bajo La Alumbrera y Veladero) se concluye que la participación estatal en la renta habría sido del $61,40 \%$ en el primer caso y del $51,74 \%$ en el segundo (Tabla 6). Sin embargo, estos resultados están sobredimensionados, dado que el modelo aplicado posee ciertas limitaciones, como vincular los costos operativos a las ventas (no reflejando las fluctuaciones de los costos de producción) e ignorar las inversiones estatales en el descubrimiento de yacimientos, mantenimiento de infraestructural vial y otros servicios públicos y los bajísimos precios cobrados por el agua y la energía eléctrica (Murguía, 2015). Como limitación adicional, debemos señalar que dicho autor incorpora a la renta minera apropiada por el Estado recursos que en la realidad no son captados (o lo son parcialmente) por aquél, como los derechos de exportación, el impuesto a las ganancias, las regalías provinciales y el impuesto a los débitos bancarios.

Realizada por Basualdo (2013), la otra estimación presentada en el Tabla 6 es más realista, en un contexto donde la participación del Estado en la renta minera es del 44,70\% en el caso de Bajo La Alumbrera y de apenas el $17,60 \%$ en el de Veladero. Nótese que este último caso, que pertenece a la segunda generación de proyectos mineros -esto es, la iniciada durante el neodesarrollismo-, muestra una participación estatal en la renta minera mucho menor que la exhibida en el caso de la mina que comenzó a operar durante el neoliberalismo, mostrando así el impacto diferencial de los beneficios adicionales otorgados por el "progresismo" al sector. Aún así, debe señalarse que esta estimación tampoco incluye las inversiones y demás erogaciones del sector público.

Lo anterior no es un dato menor, dado que el Estado ha transferido una vasta masa de activos públicos para usufructo y enriquecimiento empresarial. Tanto durante el modelo neoliberal como bajo el neodesarrollismo, las millonarias inversiones en capital fijo requeridas para la explotación de los yacimientos fueron externalizadas al Estado, quien asumió la responsabilidad por mejorar caminos y puentes, ceder tierras fiscales, expropiar tierras privadas, realizar obras de adaptación de la red hídrica, energética y vial y garantizar un ilimitado abastecimiento de gas y electricidad a través del tendido de líneas de alta tensión (500 $\mathrm{kV}$ ), la ampliación de gasoductos troncales, la relocalización de usinas térmicas, el tendido de electroductos aéreos en alta tensión y la entrega de energía a precios subsidiados exentos de futuras indexaciones y modificaciones del Tabla tarifario. Otra continuidad entre ambas fases atañe a los reembolsos a las exportaciones por régimen general del 2,5\%-10,5\% del valor comercializado que, desde 1993 hasta la fecha, han sido otorgados a las mineras transnacionales con operaciones en el país, en algunos casos rebasando los montos anuales erogados por las empresas en concepto de regalías y salarios.

Otro caso digno de mencionar es la ya mencionada reactivación de los reintegros a las

Tabla 6. Participación estatal y privada en la renta minera metalífera (en \%), Argentina, casos y períodos seleccionados

\begin{tabular}{l|c|c|c|c|c|c}
\hline \multicolumn{3}{c|}{ Murguía (2015) } & \multicolumn{3}{c}{ Basualdo (2013) } \\
\hline Mina & Período & \% renta pública & \% renta privada & Período & \% renta pública & \% renta privada \\
\hline Bajo La Alumbrera & $1997-2012$ & 61,40 & 38,60 & $2005-2009$ & 44,70 & 55,30 \\
Veladero & $2005-2012$ & 51,74 & 48,26 & $2006-2010$ & 17,60 & 82,40 \\
\hline
\end{tabular}

Fuente: elaboración propia sobre la base de Basualdo (2013) y Murguía (2015). 
exportaciones por puertos patagónicos. Dado que para las mineras extranjeras dichos reembolsos habrían representado en 2015 ingresos por 148 millones de dólares (MEyM, 2016b), esa política anuló o revirtió los exiguos ingresos que el erario obtuvo ese año (128 millones de dólares) como derecho de exportación (CAEM, 2017), neutralizando una de las escasas herramientas con las que el Estado nacional participaba en la renta del sector (Basualdo, 2013). Lo anterior tampoco contempla los subsidios directos otorgados por gobiernos provinciales, que en ciertos casos han socializado los costos privados de producción y el riesgo empresario suspendiendo el cobro de tasas, impuestos, cánones y regalías y asumiendo el pago de electricidad, agua, combustible y cargas laborales.

En cuanto al segundo punto, continuó vigente la prohibición dispuesta durante la década de 1990 por el Código de Minería respecto de la propiedad, gestión y explotación estatal del recurso, excepto en caso de asociación con inversores privados. Durante la fase neoliberal algunas firmas estatales preexistentes como YMAD (Catamarca), Cormine (Neuquén) y Fomicruz (Santa Cruz) se habían incorporado como socias marginales a la operatoria de algunos proyectos, fenómeno que continuó durante el neodesarrollismo cuando la flamante Organización Federal de Estados Mineros otorgó a las provincias la potestad de constituir nuevas empresas públicas -CEyMSE (Catamarca) y JEMSE (Jujuy), entre otras- y participar en la renta. Continuando la lógica heredada del extractivismo neoliberal, esto no significó una pérdida de peso relativo del empresariado transnacional en manos del Estado, sino más bien una cooptación del aparato burocrático por parte del capital, que pasó así a disponer de recursos técnicos, económicos y/o humanos públicos y de legitimidad jurídica, moral, política e institucional ante la creciente resistencia social al modelo extractivo.

Lo anterior conduce a otro rasgo que Gudynas (2012) considera intrínseco al rol garantista del Estado en el marco de un modelo extractivo clásico: minimizar, negar y/o reprimir la protesta ciudadana, algo que paradójicamente no ocurrió durante el período neoliberal sino durante la fase neodesarrollista. Articulándose a las políticas corporativas asistencialistas y clientelistas de responsabilidad social empresarial del capital, el Estado buscó volver razonable e incluso deseable "la Argentina minera" (Svampa y Antonelli, 2009, p.19) mediante una fábula desarrollista y una retórica filantrópica preñada de metáforas (creación de empleo y riqueza, efecto-derrame, fortalecimiento de economías regionales, saneamiento de cuentas públicas, desarrollo local). Ante el fracaso de esta táctica, la clase política llegó al extremo de considerar todo discurso contestatario al modelo como sinónimo de locura, mentira o imaginario conspirativo (Antonelli, 2011), acusando a las organizaciones ambientalistas opuestas a la actividad de perseguir el espurio objetivo de mantener las provincias mineras sumidas en la pobreza. El Estado produce y difunde entonces datos tranquilizadores sobre las "seguras" condiciones de explotación; silencia e invisibiliza conflictos; sindica como enemigos del progreso a los opositores a la actividad; utiliza sesgadamente la legalidad institucional; impide, malogra y/o desconoce plebiscitos donde la población se expresa contra el modelo; y utiliza el aparato jurídicorepresivo para criminalizar y reprimir la protesta, y fomentar la militarización $y$ contrainsurgencia.

Ejemplo de esto último es la Ley Antiterrorista sancionada en 2011, cuyas deliberadamente vagas e imprecisas definiciones permiten criminalizar y perseguir la protesta social ${ }^{14}$ (Mekler, 2013). Si bien dicha norma excluye de punición hechos asociados al ejercicio de los derechos humanos, sociales y/o constitucionales, sugestivamente fue aplicada por primera vez para reprimir e imputar a manifestantes que protestaban pacíficamente contra la minería metalífera, permitiendo a fuerzas policiales

14 En el marco de esta ley, las causas no son excarcelables y el procedimiento de prueba está invertido, obligando a los imputados a probar que no son terroristas. 
locales, grupos especiales de elite provincial e infantería nacional desarrollar encarcelamientos injustificados sin respetar jurisdicciones, normativas y procedimientos legales habituales (Mekler, 2013).

\section{Conclusiones}

Porosos y ambivalentes, los límites entre extractivismo clásico neoliberal y neoextractivismo "progresista" en Argentina se desdibujan, diseñando una suerte de continuum o transversalidad donde el neodesarrollismo completó el proceso de reprimarización, extranjerización, privatización, concentración y depredación iniciado a finales del siglo XX. Ello explica la paradoja opuesta a lo planteado por Gudynas de que, pese a la creciente participación del Estado como regulador y apropiador de renta, la importante presencia previa del capital privado foráneo se haya mantenido e incluso expandido durante el neodesarrollismo. Los tres estudios de caso desarrollados en este trabajo, que en su conjunto son responsables por más de la mitad de las exportaciones nacionales, demuestran que el modelo extractivo argentino no es puro, sino extremadamente contradictorio, compuesto de actividades cuyo desempeño se ajusta parcialmente a la dinámica "progresista" sugerida por la literatura y sectores donde perdura casi intacto el rol subsidiario clásico del Estado.

Tanto el agronegocio como la pesca marítima y la minería metalífera comparten numerosos rasgos en común: vocación exportadora casi absoluta; enorme peso del capital concentrado extranjero; explícita cosustanciación ideológica, técnica, política y económica gubernamental con el modelo; y catastróficas consecuencias sociales, económicas, productivas, ambientales, ecológicas y sanitarias. En ninguno de los tres casos el Estado nacional ha creado empresas públicas que intervengan directa y/o mayoritariamente en la gestión y/o explotación de los recursos naturales implicados. Sin embargo, existen diferencias sustantivas entre las políticas públicas implementadas respecto de la captación y redistribución del excedente generado por estos sectores.
El agronegocio y, sobre todo, el extractivismo sojero muestran una dinámica más asociada a los presupuestos teóricos de la literatura de referencia, verificándose un papel activo del Estado neodesarrollista plasmado en la intervención en el mercado granario y la apropiación nominal de un tercio de la renta vía derechos de exportación. Dejando intactas las bases de sustentación legadas por el neoliberalismo, el impacto real de esa política fue relativizado por la devaluación monetaria, el alza de los precios internacionales y las políticas de distribución de cupos exportables y subsidio a las grandes corporaciones. No obstante los tibios intentos progresistas de canalizar parte del excedente hacia el financiamiento de programas asistencialistas, el principal objetivo de la regulación estatal fue la defensa de los intereses de aquellas facciones del capital que gozaban de fluidos vínculos con el poder político, mientras que los resultados de la intervención gubernamental en el agronegocio respecto de la reducción de la pobreza y el desarrollo socioeconómico han sido discutibles y poco claros.

El caso de la pesca marítima no mostró mayor presencia del Estado en la imposición de andamiajes regulatorios estrictos y captación de una parte sustancial del excedente. Al contrario, el modelo legado por el neoliberalismo continuó prácticamente intacto bajo el neodesarrollismo, acentuando la primacía de actores corporativos transnacionalizados (la flota extranjera y mixta), el rol subsidiario y garantista del aparato político, la maduración de las reformas concebidas durante la década neoliberal y la ausencia de cualquier rasgo que remotamente pueda ser juzgado como progresista. Exceptuando la imposición de exiguos derechos de exportación, el gobierno nacional casi no ha participado en la apropiación de la renta pesquera y cuando lo hizo, resignó esos magros ingresos en manos del capital privado a través de otros mecanismos normativos, no existiendo margen ni intencionalidad de canalizarlos hacia el resto de la sociedad.

El caso más extremo corresponde a la minería metalífera, un sector donde no se han desarrollado políticas activas de captación del excedente. Lejos de aumentar tributos e incrementar 
su participación en la renta, el Estado transitó el camino exactamente opuesto: desplegó reformas normativo-institucionales que preservaran las ganancias del sector transfiriendo una vasta masa de activos públicos al capital. La continuidad y ampliación de las generosas ventajas otorgadas por el neoliberalismo, la tardía (y en gran medida infructuosa) política de retenciones a las exportaciones, la extranjerización casi total del sector, la privatización del patrimonio público, el apaciguamiento de la protesta ciudadana, los subsidios directos e indirectos y los mecanismos de reembolso a las exportaciones dan pábulo a la tesis de un esquema garantista de acumulación donde el Estado literalmente financia el saqueo de los recursos minerales nacionales.

No parece existir entonces correlación empírica general unívoca entre papel más activo del Estado, menor peso del capital extranjero y mayor apropiación pública de la renta exportadora, ni tampoco oposición frontal paradigmática entre neoliberalismo y neodesarrollismo. Así, el modelo extractivo argentino evoca las palabras de Rajland (2012, pp. 257-258) respecto de que el debate entre Estado neoliberal (que no regula) y posneoliberal (que sí lo hace) es estéril, dado que indefectiblemente el aparato político siempre intervendrá en resguardo y reaseguro de los intereses hegemónicos.

\section{Referencias}

Acosta, A. (2016). Las dependencias del extractivismo. Aporte para un debate incompleto. Actuel Marx Intervenciones, (20), s/p. Recuperado de http://aldhea.org/ las-dependencias-del-extractivismo-aporte-para-un-debate-incompleto/

Álvarez, L. (2017). Minería, dinamismo y despojo. RELACSO, (10), s/p. doi: 10.18504/rlo110-005-2017

Antonelli, M. (2011). Megaminería, desterritorialización del Estado y biopolítica. Astrolabio, (7), 3-22.

Basualdo, F. (2013). Desempeño de la actividad minera metalífera en la Argentina. Renta minera y distribución de los beneficios. Recuperado de http://www.iade.org.ar/uploads/c87bbfe5-7dbo-7cod. pdf

Brunhes, J. (1942). La Géographie humaine. París, Francia: PUF.

Burchardt, H. J. \& Dietz, K. (2014). (Neo)extractivism - a new challenge for development theory from Latin America. Third World Quarterly, 35(3), 468-486.

CAEM. (2015). Minería argentina. Todas las respuestas. Aspectos económicos. Buenos Aires, Argentina: Cámara Argentina de Empresarios Mineros.

CAEM. (2017). Reposición de retenciones. Impacto social y fiscal. Industria minera. Buenos Aires, Argentina: Cámara Argentina de Empresarios Mineros.

CIARA. (2016). Estadísticas nacionales. Buenos Aires, Argentina: Cámara de la Industria Aceitera de la República Argentina. Recuperado de http://www.ciaracec.com.ar/estadisticasNac.php

Cóccaro, J. M., Le Bail, J., Gómez, O. y Boetto, A. (2000). La minería pesquera ¿argentina?. Ponencia llevada a cabo en el II Encuentro Internacional Humboldt, Mar del Plata, Argentina.

Composto, C. (2012). Acumulación por despojo y neoextractivismo en América Latina. Una reflexión crítica acerca del Estado y los movimientos socio-ambientales en el nuevo siglo. Astrolabio, (8), 323-352.

Cortese, C., del C. Llano, M. y equipo. (2013). El modelo "productivo con inclusión social»: una modalidad de redistribución de ingresos manteniendo la concentración de la riqueza. Revista Confluencia, (13), 83-117. 
Modelo extractivo en Argentina (1990-2016): ¿del extractivismo clásico neoliberal al neoextractivismo progresista? Tres estudios de caso

DEP. (2016a). Desembarques por especie, puerto y flota (años seleccionados). Buenos Aires, Argentina: Dirección de Economía Pesquera.

DEP. (2016b). Exportaciones pesqueras: Comportamiento de los principales mercados 2015. Buenos Aires, Argentina: Dirección de Economía Pesquera.

Féliz, M. (2012). Neoextractivismo, neodesarrollismo y proceso de acumulación de capital: ¿superando el ciclo de stop-and-go? Argentina, 2003-2012. Ponencia llevada a cabo en las VII Jornadas de Sociología de la UNLP, La Plata, Argentina.

Fratini, S. (2006). Causas de la depredación pesquera durante la década de 1990. En J. Morina (Ed.), Neoliberalismo y problemáticas regionales en Argentina. Interpretaciones geográficas (pp. 133-147). Luján, Argentina: UNLU.

Frechero, J. I. (2013). Neoextractivismo e inserción internacional. Hacia una Argentina económica y ecológicamente dependiente. En A. M. Fernández (Ed.), Territorios, economía internacional y conflictos socioambientales (pp. 59-101). Tandil, Argentina: IGEHCS.

FVSA. (2008). Crisis de la pesca de merluza. Estado de situación, implicancias y propuestas. Buenos Aires, Argentina: Fundación Vida Silvestre Argentina.

Giancola, S., Salvador, M., Covacevich, M. e Iturrioz, G. (2009). Análisis de la cadena de soja en la Argentina. Buenos Aires, Argentina: INTA.

Giarracca, N. y Teubal, M. (2013). Las actividades extractivas en la Argentina. En N. Giarracca y M. Teubal (Eds.), Actividades extractivas en expansión: ¿reprimarización de la economía argentina? (pp. 159-172). Buenos Aires, Argentina: Antropofagia.

Gudynas, E. (2009). Diez tesis urgentes sobre el nuevo extractivismo. Contextos y demandas bajo el progresismo sudamericano actual. En VVAA (Eds.), Extractivismo, política y sociedad (pp. 187-225). Quito, Ecuador: CAAP-CLAES.

Gudynas, E. (2012). Estado compensador y nuevos extractivismos. Las ambivalencias del progresismo sudamericano. Nueva Sociedad, 237, 128-146.

Gudynas, E. (2015). El desarrollo revisitado desde los debates sobre los extractivismos y sus alternativas. Recuperado de https://www.uhu.es/IICIED/pdf/2_1_extract.pdf

INAP. (1999). El sector pesquero marplatense: una aproximación diagnóstica del actual y futuro escenario ante la emergencia de la Ley de Pesca. Buenos Aires, Argentina: Instituto Nacional de la Administración Pública.

INDEC. (2014). Porcentaje de hogares y personas bajo las líneas de pobreza e indigencia en los aglomerados urbanos y regiones estadísticas desde el primer semestre 2003 en adelante. Buenos Aires, Argentina: Instituto Nacional de Estadística y Censos.

La Política Online. (13 de marzo de 2013). El Fondo Sojero creado por Cristina al final se gasta en sueldos de estatales. La Política Online. Recuperado de http://www.lapoliticaonline.com/nota/70210/

Lauffer, R. (2009). China y Argentina. ¿Nuevos rumbos para la vieja dependencia?. Ponencia llevada a cabo en las XII Jornadas Interescuelas/Departamentos de Historia, San Carlos de Bariloche, Argentina.

Lander, E. (2014). El neoextractivismo como modelo de desarrollo en América Latina y sus contradicciones. Recuperado de https://mx.boell.org/sites/default/files/edgardolander.pdf

Machado Aráoz, H. (2013). Orden neocolonial, extractivismo y ecología política de las emociones. Revista Brasileira de Sociología da Emoção, 12 (34), 11-43. 
Mekler, I. (2013). El Estado Minero: leyes, derechos y voluntad popular. Ponencia llevada a cabo en las $\mathrm{X}$ Jornadas de Sociología, Buenos Aires:, Argentina.

MEyM. (2016a). Informes de cadenas de valor. Minería metalífera y rocas de aplicación. Buenos Aires, Argentina: Ministerio de Energía y Minería de la Nación.

MEyM. (2016b). Reembolsos por puertos patagónicos. Consideraciones para el sector minero. Buenos Aires, Argentina: Ministerio de Energía y Minería de la Nación.

MH-INDEC. (2017). Complejos exportadores 2016. Buenos Aires, Argentina: Ministerio de HaciendaInstituto Nacional de Estadística y Censos.

MINAGRI. (2016). Estadísticas agrícolas, por cultivos, campañas, provincias y departamentos. Buenos Aires, Argentina: Ministerio de Agroindustria de la Nación.

Montenegro, M. (2011). Es la Ekonomía, estúpido. La historia secreta de las decisiones, trampas y falacias del kirchnerismo. Buenos Aires, Argentina: Planeta.

Muleiro, V. (2000). Saqueo en alta mar. Diario Clarín, s/p.

Murguía, D. (2015). Minería metalífera multinacional en Argentina: su costo de oportunidad económico-estatal y escenarios alternativos. Revista Iberoamericana de Economía Ecológica, (24), 57-70.

Osiroff, S. (2009). La pesca en Tierra del Fuego. Río Grande, Argentina: UTN.

Página 12. (6 de abril de 2015). Lo que reparte el fondo de la soja. Página 12. Recuperado de https:// www.paginal2.com.ar/diario/economia/2-269820-2015-04-06.html

Palma, A. y Cantamutto, F. (2016). Hegemonía y discurso: La polémica por las retenciones móviles en la Argentina (2008). Documentos de Trabajo del CEISO, (1), 56-97.

Palmisano, T. (2014). Los señores de la tierra. Transformaciones económicas, productivas y discursivas en el mundo del agro bonaerense (tesis doctoral). Universidad Nacional de Buenos Aires, Buenos Aires, Argentina.

Paulinovich, L. (2013). La ilusión derrotada. Recuperado de http://www.brujulacomunicacion.com/ index.php/cooperativa/periodico-sursuelo/item/242-la-ilusion-derrotada

Pierri, J. (2006). El boom de la soja. Un retorno al pasado. Realidad Económica, (219), 53-65.

Portillo, L. (2014). Extractivismo clásico y neoextractivismo. ¿Dos tipos de extractivismos diferentes? Revista de la Facultad de Ciencias Económicas y Administrativas, 15(2), 11-29.

Porto, A. (2009). Efecto fiscal de los impuestos sobre las exportaciones. Rosario, Argentina: BCR.

Rajland, B. (2012). El estado del Estado en la Argentina después de 2001. Continuidades y rupturas. En M. Thwaites (Ed.), El Estado en América Latina: continuidades y rupturas (pp. 255-278). Buenos Aires, Argentina: CLACSO.

Rameri, A., Haimovich, A., Lozano, C. y Raffo, T. (2014). 36,5\% de pobres y 12,1\% de indigentes: los números que el gobierno pretende ocultar. Buenos Aires, Argentina: IPyPP.

Ruiz, M. (2014). La devastación socioambiental del capitalismo en la era del Antropoceno. Mundo Siglo XXI, revista del CIECAS-IPN, 32(9), 33-46.

Sández, F. (2016). La Argentina fumigada. Agroquímicos, enfermedad y alimentos en un país envenenado. Buenos Aires, Argentina: Planeta.

Santos, M. (1996). A natureza do espaço. Técnica e tempo, razão e emoção. São Paulo, Brasil: Hucitec. 
Santos, M. y Silveira, M. L. (2001). O Brasil. Território e sociedade no início do século XXI. Rio de Janeiro-São Paulo, Brasil: Record.

Seoane, J. (2013). Modelo extractivo y acumulación por despojo. En J. Seoane, E. Taddei y C. Algranati (Eds.), Extractivismo, despojo y crisis climática. Desafíos para los movimientos sociales y los proyectos emancipatorios de Nuestra América (pp. 21-40). Buenos Aires, Argentina: Herramienta-El Colectivo-GEAL.

Silveira, M. L. (1999). Um país, uma região. Fim de século e modernidades na Argentina. São Paulo, Brasil: LABOPLAN-USP.

SM. (2008). Minería en números, 2008. Buenos Aires, Argentina: Secretaría de Minería.

Svampa, M. (2011). Extractivismo neodesarrollista, gobiernos y movimientos sociales en América Latina. Problèmes d'Amérique Latine, (80), s/p.

Svampa, M. y Antonelli, M. (2009). Hacia una discusión sobre la megaminería a cielo abierto. En M. Svampa y M. Antonelli (Eds.), Minería transnacional, narrativas del desarrollo y resistencias sociales (pp. 15-27). Buenos Aires, Argentina: Biblos.

Teubal, M. y Rodríguez, J. (2002). Agro y alimentos en la globalización. Una perspectiva crítica. Buenos Aires, Argentina: La Colmena.

Teubal, M. y Palmisano, T. (2013). Crisis alimentaria y crisis global: la Argentina de 2001/2002 y después. Realidad Económica, (279), 47-74.

Teubal, M. y Palmisano, T. (2015). ¿Hacia la reprimarización de la economía? En torno del modelo extractivo en la posconvertibilidad. Realidad Económica, (296), 55-75. 